\title{
Mammary Amylase: a Possible Alternate Pathway of Carbohydrate Digestion in Infancy
}

\author{
LEO A. HEITLINGER, PING C. LEE, WILLIAM P. DILLON, AND EMANUEL LEBENTHAL ${ }^{(31)}$ \\ Division of Gastroenterology and Nutrition, Department of Pediatrics, Children's Hospital and the State University of \\ New York, Buffalo, New York, USA
}

\begin{abstract}
Summary
Mammary amylase is a possible alternate pathway of digestion of glucose polymers and starches, that is most important in early infancy when pancreatic amylase is low or absent in duodenal fluid and responds poorly to stimuli. Human breast milk contains $\mathbf{1 0 0 0}$ 5000 units of amylase/liter. In order to evaluate the likelihood that a significant proportion of mammary amylase activity would withstand passage through the stomach, purified and unpurified mammary anylase were exposed to acid and pepsin in vitro to simulate the gastric environment found in young infants. Both purified and unpurified enzymes were stable at $\mathrm{pH} 7.5$ with little or no activity lost after $4 \mathrm{~h}$, and approximately $80 \%$ retained at 6 h. When incubated at pH 3.5 , one-third of unpurified enzyme activity was retained for $6 \mathrm{~h}$; in contrast, the purified enzyme was acid labile losing $80 \%$ by 2 h. Addition of bovine serum albumin or breast milk proteins to purified enzyme protected the activity. When unpurified enzyme was exposed to a stepwise decline in $\mathbf{p H}$ from 6.5 to 3.5 over $4 \mathrm{~h}, 50 \%$ of the original activity was retained. Unless the concentration was $\geq \mathbf{3 7 5 0}$ units $/ \mathrm{ml}$, the addition of varying concentrations of pepsin to defatted breast milk incubated at pH 3.5 did not affect any greater decay of enzyme activity despite evidence of peptic digestion of proteins in the reaction mixture. This study supports the possibility that ingested mammary amylase could retain a significant proportion of its original activity after exposure to acid and pepsin in the stomach of young infants.
\end{abstract}

\section{Speculation}

Mammary amylase may be an enzyme important to carbohydrate digestion in infancy. The amount that would survive passage through the stomach of a young infant is most probably greater than would be contained in the pancreatic secretions of infants less than approximately 4-6 months of age. The physiologic importance of mammary amylase may be analogous to that of the bile salt stimulated lipase found in human milk.

Term and premature infants have low concentrations of amylase (EC 3.2.1.1) in serum $(3,12)$, urine $(28)$, and duodenal fluid $(2,6$, $14,15,30)$ that do not reach adult levels until the second year of life. Many infants, particularly those who have increased caloric demands, receive glucose polymers and starch very early in life, from infant formulas and beikost respectively. The amount of complex carbohydrate that is digested, absorbed, and utilized by young infants is unknown (13); the nutritionally comprised infant, who is most likely to receive diets containing starches and polymers of glucose, seems to be most at risk of developing carbohydrate malabsorption $(8,18)$.

Glucose polymer intolerance, presenting in the young infant, has not been adequately addressed in the clinical situation. This may be due to failure of recognition by parents and physicians, or to the presence of supplemental alternate pathways. Alternative enzymes for hydrolysis of glucose polymers during physiologic deficiency of pancreatic amylase include: salivary amylase, small intestinal brush border glucoamylase (EC 3.2.1.3), and mammary amylase in the breast fed infant. Salivary amylase is present in infancy, and reaches adult levels much earlier than pancreatic amylase $(4,24)$. Glucoamylase reaches levels equal to those of young adults as early as 1 month of age (16). Mammary amylase is highest in colostrum, but has substantial activity in the range of 1000-5000 units/liter, even after 6 months of lactation $(9,11)$; their concentrations are twenty-five times that of cow's milk (25). The relative clinical importance of these three enzymes is unclear.

The physiologic importance of mammary amylase in the digestion of glucose polymers and starches is dependent on many factors; perhaps the most important is the potential inactivation by gastric acid and pepsin. In order to evaluate the likelihood that a significant proportion of mammary amylase activity would withstand passage through the stomach, purified and unpurified mammary amylase were exposed to acid and pepsin in vitro to simulate the gastric environment found in young infants.

\section{MATERIALS AND METHODS}

Amylase sources and purification. Human breast milk was obtained by manual expression, from healthy volunteers who delivered at term. The protocol was approved by the Institutional Review Board, and informed consent was obtained. The samples were collected over ice and then frozen immediately after collection. For experiments, the raw milk was thawed and centrifuged for 1 min (Microfuge B, Beckman, Palo Alto, CA). The fat and pellet were removed. The remaining fluid was used as unpurified, defatted milk in the experiments below, or for purification. Specimens were pooled, then filtered with suction through five thicknesses of glass fiber filter. The filtrate was dialyzed against acetate buffer $(50 \mathrm{mM})$ and calcium chloride $(2 \mathrm{mM}), \mathrm{pH} 5.5$, overnight. Ten $\mathrm{ml}$ of the dialyzed preparation was loaded on an affinity gel column containing $2 \mathrm{ml}$ of Sepharose 6B, epoxy activated (Pharmacia, Uppsala, Sweden), with cyclodextrin (Sigma, St. Louis, MO) as the ligand, prepared according to Vretblad (29). The column was washed with ten volumes of acetate buffer, or until no protein could be detected in the eluant. The amylase was eluted by cyclodextrin in the same buffer $(8 \mathrm{mg} / \mathrm{ml})$. Fractions containing amylase were pooled and concentrated by ultrafiltration (PM10, Amicon, Lexington, MA). The concentrate typically contained approximately 20 units of amylase $/ \mathrm{ml}$ with no detectable protein by the Lowry method. When further concentrated, a single band corresponding to the amylase activity was seen on polyacrylamide gel electrophoresis when stained with Coomassie blue. Recovery ranged from $60-75 \%$ of the initial activity. The concentrate was frozen until used.

Amylase assay. Blue insoluble starch tablets (Phadebas, Pharmacia, Uppsala, Sweden) were suspended in a phosphate buffer (20 mM), pH 7.0, to which $5 \mathrm{mg} / \mathrm{ml}$ bovine serum albumin, fraction V (Miles Laboratories, Elkhardt, IN) had been added in order to give results comparable to the saccharogenic method with soluble starch and dinitrosalicylic acid (23). A standard curve was generated using Monitrol I chemistry control (Dade, Miami, Florida). In none of the experiments below, did the addition of the 
10-25 $\mu 1$ aliquot of sample to be tested change the $\mathrm{pH}$ of the assay system significantly.

Protein assay. Protein was assayed by the method of Lowry (19) with bovine serum albumin as the standard.

Peptide assay. Trichloroacetic acid soluble peptides were detected by the ninhydrin reaction (22) with leucine as the standard.

Statistics. The $t$ test for unpaired means was used as a test of statistical significance $(P<0.01$ unless otherwise indicated).

\section{RESULTS}

Experiment 1 . Purified and unpurified mammary amylase were incubated at $37^{\circ} \mathrm{C}$ after $1: 2$ dilution (v/v) with the appropriate buffer; the $\mathrm{pH}$ of the reaction mixture was measured and titrated, when necessary with $5 \%$ acetic acid. Two buffer systems were used: (1) $\mathrm{pH} 3.5$, sodium acetate $(50 \mathrm{mM})$ and calcium chloride $(2 \mathrm{mM})$ and $(2) \mathrm{pH} 7.5$, Tris acetate $(50 \mathrm{mM})$ and calcium chloride ( $2 \mathrm{mM})$. The purified amylase at $\mathrm{pH} 3.5$ was incubated without added protein, or with bovine serum albumin or breast milk protein at the same concentration as the diluted, defatted breast milk. Breast milk protein was prepared by heating defatted breast milk at $70^{\circ} \mathrm{C}$ for $1 \mathrm{~h}$; no residual amylase activity was detected. Aliquots were removed from all incubation mixtures at intervals and checked for amylase activities. The results were calculated as the $\%$ of the original activity that was retained and presented in Figure 1. Both purified and unpurified enzymes were stable at $\mathrm{pH}$ 7.5 with little or no activity lost after $4 \mathrm{~h}$, and approximately $80 \%$ of the original activity retained even after $6 \mathrm{~h}$. The defatted breast milk when incubated at $\mathrm{pH} 3.5$, retained nearly one-half of its original activity at $2 \mathrm{~h}$, and approximately one-third at $6 \mathrm{~h}$. The purified material decayed more rapidly $(P<0.01)$ losing $80 \%$ of the original activity at $2 \mathrm{~h}$. The addition of bovine serum albumin or breast milk protein gave results not significantly different than the unpurified material.

Experiment 2. Defatted milk, diluted with acetate buffer $(50$ $\mathrm{mM}$ ) at $\mathrm{pH} 6.5$ was incubated for $6 \mathrm{~h}$ at $37^{\circ} \mathrm{C}$ with a gradual decrease of the $\mathrm{pH}$ of the mixture, by addition of $5 \%$ acetic acid, to simulate the $\mathrm{pH}$ changes after a breast milk feeding. The $\mathrm{pH}$ was measured hourly with a glass electrode. For selection of the appropriate $\mathrm{pHs}$, we adapted the data from a study of postprandial

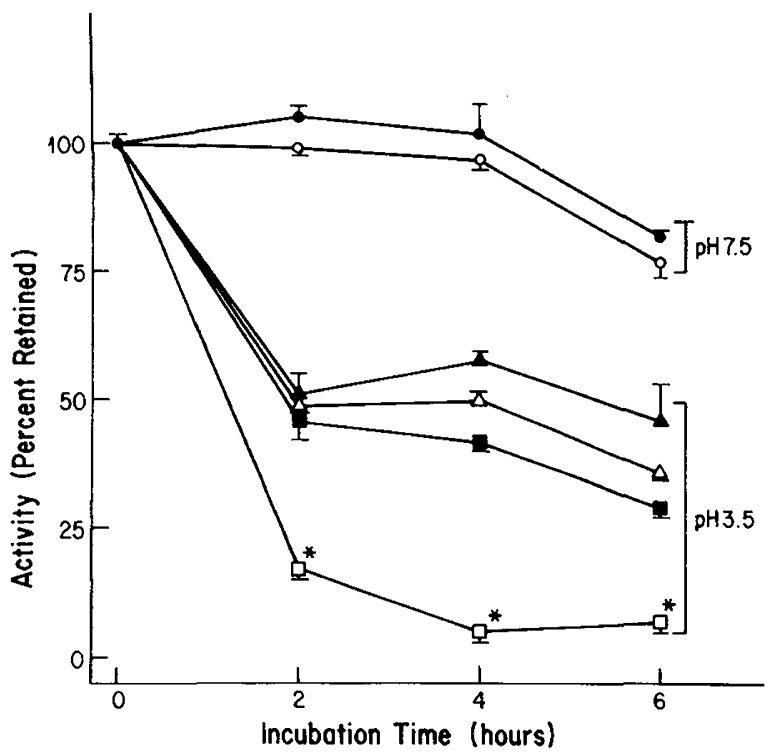

Fig. 1. Stability of purified and unpurified mammary amylase at neutral and acid $\mathrm{pH}$ (mean \pm S.D., $n=3$ ). All points at $\mathrm{pH} 3.5$ are statistically significantly lower than those at $\mathrm{pH} 7.5$ Asterisks indicate the points that are significantly lower than the defatted breast milk at pH $3.5(P<0.01)$. Closed circles and squares, unpurified mammary amylase; open circles and squares, purified mammary amylase without added proteins; closed triangles, purified mammary amylase with added bovine serum albumin; and open triangles, purified mammary amylase with added breast milk proteins.

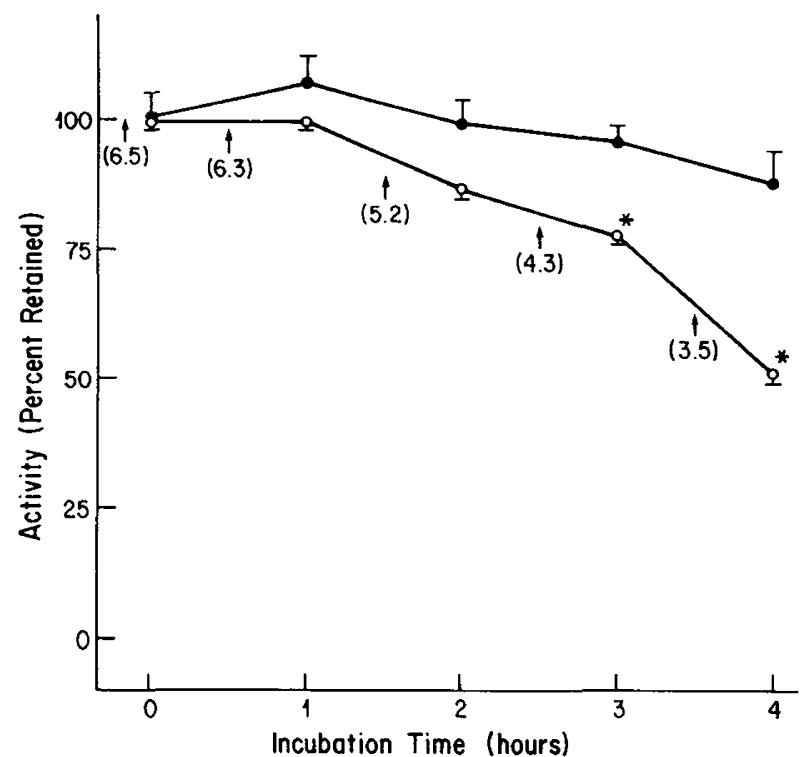

Fig. 2. Stability of incubated unpurified mammary amylase with decreasing $\mathrm{pH}$ (mean \pm S.D., $n=3$ ). Numbers in parentheses indicate the $\mathrm{pH}$. Asterisks indicate points statistically different than the control at $\mathrm{pH}$ $6.5(P<0.01)$. Open circles, sample exposed to decreasing $\mathrm{pH}$ and closed circles, control at $\mathrm{pH} 6.5$ for the duration of the experiment.

intragastric $\mathrm{pH}$ of newborns (20), which agrees with data collected from our own nursery. The material was sampled at intervals, and compared to defatted breast milk incubated in acetate buffer at a constant $\mathrm{pH}$ of 6.5 . The data were calculated as the $\%$ of the original activity that was retained and presented in Figure 2. More than $50 \%$ of the original activity was retained for $4 \mathrm{~h}$, in the sample exposed to the gradual decrease in $\mathrm{pH}$. When compared to the control held at $\mathrm{pH} 6.5$ for the duration of the experiment, the declining $\mathrm{pH}$ did not elicit more rapid decay until $3 \mathrm{~h}$, when $\mathrm{pH}$ was decreased to $4.3(P<0.01)$.

Experiment 3. Defatted milk in acetate buffer, pH 3.5, was incubated at $37^{\circ} \mathrm{C}$ with several concentrations of pepsin (EC 3:4:23:1) (1:10,000, Sigma, St. Louis, MO), and compared to a control without pepsin. The aliquots were removed and assayed for amylase at intervals, and the results were calculated as the \% of the original posttitration activity at $\mathrm{pH} 3.5$ that was retained. At the completion of the incubation, trichloroacetic acid was added to a final concentration of $5 \%$ to separate the acid soluble and insoluble fractions. The precipitate was resuspended in sodium carbonate buffer $(4 \% \mathrm{w} / \mathrm{v})$ and assayed for protein by the Lowry method. The supernatant was assayed for soluble peptides by the ninhydrin method as described above. The addition of less than 3750 units of pepsin $/ \mathrm{ml}$ did not affect any greater decay than the effect of $\mathrm{pH} 3.5$ alone, for at least $4 \mathrm{~h}$ (Fig. 3). Greater concentrations of pepsin were associated with a rapid decay in activity, as early as $2 \mathrm{~h}$, with no remaining activity by $4 \mathrm{~h}(P<$ $0.001)$. At the lower concentrations, the lack of decay occurred despite a decrease in the acid precipitable protein. The increase in the acid soluble fraction was evidence of peptic digestion of proteins in the reaction mixture (Fig. 4).

\section{DISCUSSION}

Mammary amylase is a potential supplemental alternate pathway of digestion of complex carbohydrates. This enzyme is present in maximum concentrations in young infants when pancreatic amylase is low in duodenal fluid and responds poorly to stimuli (15). Both salivary and mammary amylases, if they are important, must either digest carbohydrate in the stomach before inactivation by acid and pepsin or regain or retain their activity when entering the duodenum. This study supports the possibility that ingested mammary amylase could retain a significant proportion of its original activity, but does not rule out preintestinal digestion. 


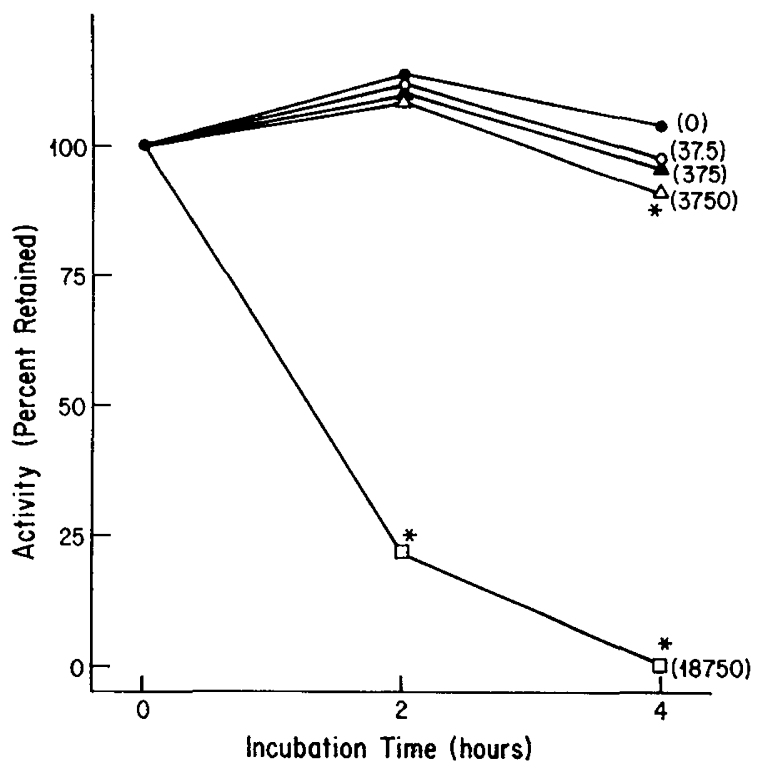

Fig. 3. Stability of unpurified mammary amylase after titration to $\mathrm{pH}$ 3.5 in the presence of pepsin (mean \pm S.D., $n=3$ ). The numbers in parentheses indicate the pepsin concentration (units/ml) for all points in the corresponding line. Asterisks indicate the points statistically different from the control without pepsin $\left(P_{3750}=<0.01, P_{18750}=<0.001\right)$.

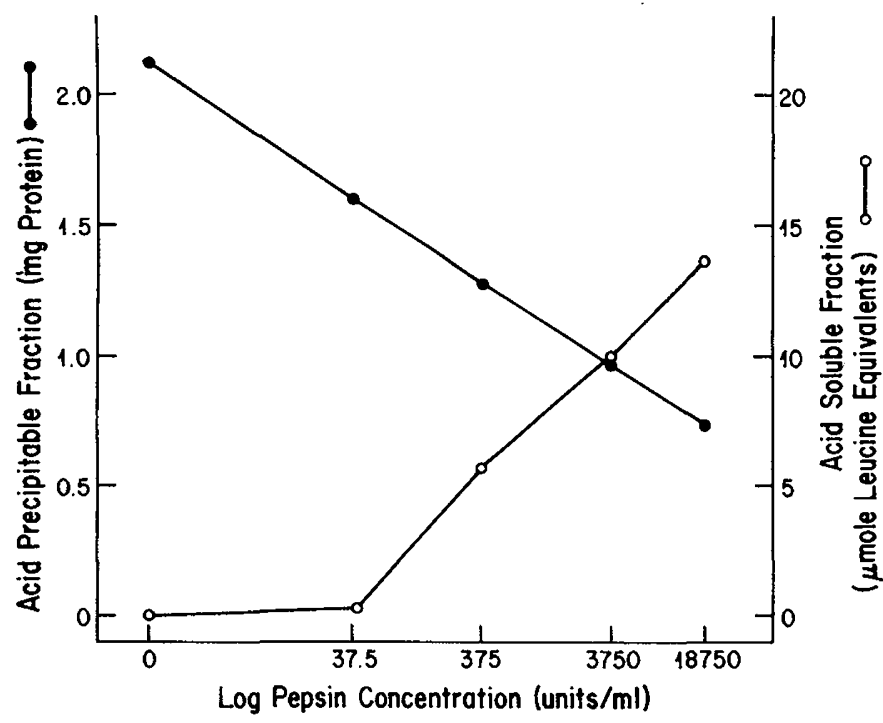

Fig. 4. Relative distribution of acid soluble and insoluble fractions after $4 \mathrm{~h}$ incubation of defatted breast milk in the presence of varying concentrations of pepsin at $\mathrm{pH} 3.5,37^{\circ} \mathrm{C}$.

Newborns and young infants secrete both acid and pepsin during fasting, but do not respond to the usual stimuli with increased acid or pepsin output $(1,7)$. The lowest intragastric $\mathrm{pH}$ and highest concentration of pepsin would then occur just before a meal; ingestion of breast milk rapidly neutralizes the acid, dilutes, and inactivates the pepsin $(20,27,5)$. The fall in $\mathrm{pH}$ after a breast milk meal probably occurs much more slowly than does emptying of the stomach; therefore, in vitro conditions used in this study are probably more severe than occurs in most infants. The estimate that $50 \%$ of activity is retained after $2-4 \mathrm{~h}$ of incubation at pH 3.5 is most probably an underestimate. Very little of the ingested mammary amylase will be exposed to that $\mathrm{pH}$, or active pepsin, sufficient to hasten decay. Even if the pepsin secreted by a young infant were to remain active, the amount secreted is far below the amount required to elicit further decay of mammary amylase activity, as indicated in the third experiment. Of further interest, the mammary amylase seems to be relatively protected by other proteins in breast milk. Proteins are digested (Fig. 4) even when little if any decay in amylase activity occurs. We do not have any data regarding which protein(s) are important, but the stabilization does appear to be significant.

An infant who is breast fed usually ingests about $150 \mathrm{ml} / \mathrm{kg}$ / day. This corresponds to approximately 450 units of amylase $/ \mathrm{kg} /$ day, an amount far greater than is present in the duodenal content of most young infants, many of whom up to the age of 3 months have no detectable pancreatic amylase even after stimulation. Under conditions more severe than would occur in most infants, approximately $50 \%$ of initial amylase activity was recovered after $4 \mathrm{~h}$ of exposure to $\mathrm{pH}$ changes similar to those attained after feeding. One might conclude that more than $200 \mathrm{units} / \mathrm{kg} / \mathrm{day}$ of active amylase might be available in the duodenum of an infant from breast milk. One report in the literature states that $75 \%$ of adults have active salivary amylase in the duodenum that contributes from $15-40 \%$ of the total activity (26). Breast fed infants may have even a greater proportion of detectable postprandial nonpancreatic amylase in their duodena; salivary and mammary amylase may both be available, even when pancreatic secretion is low. The possibility of preintestinal starch digestion in infancy remains to be investigated.

These findings suggest a role for mammary amylase analogous to that of the bile salt stimulated lipase of human milk (21). An exogenous enzyme found in human milk is active in the duodenum, compensating for low or absent pancreatic enzymes that play the major role in lipid and starch digestion in older children and adults. Endogenous salivary amylase and ligual lipase $(10,17)$ may supplement the exogenous enzymes of human milk in digestion of carbohydrate and fat in the physiologic pancreatic deficiency of early infancy.

\section{REFERENCES AND NOTES}

1. Agunod, M., Yamaguchi, N., Lopez, R., Luhby, A. L., and Jerzy-Glass, G. B.: Correlative study of hydrochloric acid, pepsin, and intrinsic factor secretion in newborns and infants. Am. J. Dig. Dis., 14: 400 (1969).

2. Auricchio, S., Rubino, A., and Murset, G.: Intestinal glycosidase activities in the human embryo, fetus and newborn. Pediatrics, 35: 944 (1965).

3. Bossuyt, P. J., Van den Bogaert, R., Scharpe, S. L., and Van Maerke, Y.: Relation of age to isoenzyme pattern and total activity of amylase in serum. Clin. Chem., 27(3): 451 (1981).

4. Collares, E. F., Brasil, M. R. L., and Kawazaki, S. T.: Secrecao de saliva, concentracao e secrecao da amilase salivar humana no primero ano de vida. Arq. Gastro. (S. Paulo), 16(2): 91 (1979).

5. Cornish-Bowden, A. J., and Knowles, J. R.: The pH dependence of pepsin catalyzed reactions. Biochem. J., 113: 353 (1969).

6. Delachaume-Salem, E., and Sarles, H.: Evolution en fonction de l'age de la secretion pancreatique humaine normale. Biol. Gastro. (Paris), 2: 135 (1970).

7. Euler, A. R., Byrne, W. J., Meis, P. J., Leake, R. D., and Ament, M. E.: Basa and pentagastrin-stimulated acid secretion in newborn human infants. Pediatr. Res., 13: 36 (1979).

8. Fisher, S. F., Leone, G., and Kelly, R. H.: Chronic protracted diarrhea: intolerance to dietary glucose polymers. Pediatrics, 67(2): 271 (1981).

9. Fridhandler, L., Berk, J. E., Montgomery, K. A., and Wong, D.: Column chromatographic studies of isoamylases in human serum, urine and milk. Clin. Chem., 20(5): 547 (1974).

10. Hamosh, M.: Fat digestion in the newborn: role of lingual lipase and preduodenal digestion. Pediatr. Res., 13: 615 (1979).

11. Jones, J. B., Mehta, N. R., and Hamosh, M.: Alpha amylase in preterm human milk. J. Pediatr. Gastro. Nutr., 1: 43 (1982).

12. Kamaryt, V. J. and Fintajslova, O.: Die entwicklung der speichel und pankreas amylase bei kindern im laufe des ersten lebensjahres. Z. Klin. Biochem., $8(6)$ : 4 (1970).

13. Lebenthal, E.: Use of modified food starches in infant nutrition. Am. J. Dis. Child, 132: 850 (1978)

14. Lebenthal, E., Choi, T. S., and Lee, P. C.: The development of pancreatic function in premature infants after milk-based and soy-based formulas. Pediatr. Res., 15: 1240 (1981).

15. Lebenthal, E. and Lee, P. C.: Development of functional response in human exocrine pancreas. Pediatrics, $66(4): 556$ (1980)

16. Lebenthal, E. and Lee, P. C.: Glucoamylase and disaccharidase activities in normal subjects and in patients with mucosal injury of the small intestine. $J$. Pediatr., 97(3): 389 (1980)

17. Levy, E., Goldstein, R., Freier, S., and Shafrir, E.: Characterization of gastric lipolytic activity. Biochim. Biophys. Acta, 664: 316 (1981).

18. Lillibridge, C. B. and Townes, P. C.: Physiologic deficiency of pancreatic amylase in infancy: a factor in iatrogenic diarrhea. Pediatrics, 82: 279 (1973).

19. Lowry, O. H., Rosebrough, N. J., Farr, A. L., and Randall, R. J.: Protein measurement with the Folin phenol reagent. J. Biol. Chem., 193: 265 (1951). 
20. Mason, S.: Some aspects of gastric function in the newborn. Arch. Dis. Child., 37: 387 (1962).

21. Mehta, M. R., Jones, J. B., and Hamosh, M.: Lipases in preterm human milk: ontogeny and physiologic significance. J. Pediatr. Gastro. Nutr., in press (1982).

22. Moore, S. and Stein, W. H.: Photometric ninhydrin method. J. Biol. Chem., I76: 367 (1948).

23. O'Donnell, M. D. and McGeeney, K. F.: Comparison of saccharogenic and Phadebas methods for amylase assay in biological fluids. Enzyme, 18: 348 (1974).

24. Rossiter, M. A., Barrowman, L. A., Dand, A., and Wharton, B. A.: Amylase content of mixed saliva in children. Acta Peditr. Scand., 63: 389 (1974).

25. Shahani, K. M., Kwan, A. J., and Friend, B. A.: Role and significance of enzymes in human milk. Am. J. Clin. Nutr., 33: 1861 (1980).

26. Skude, G. and thse, I.: Salivary amylase in duodenal aspirates. Scand. J. Gastro., 7: 17 (1976).

27. Taylor, W. H.: Studies on gastric proteolysis. Biochem. J., 71: 73 (1959).
28. Tye, J. G., Karn, R. C., and Merritt, A. D.: Differential expression of salivary and pancreatic human amylase loci in prenatal and postnatal development. $\mathbf{J}$. Med. Genet., 13: 96 (1976)

29. Vretblad, P.: Immobilization of ligands for biospecific affinity via their hydroxyl groups. The cyclohexa amylose-amylase system. Febs. Letters, 47: 86 (1974).

30. Zoppi, G., Andreotti, G., Pajno-Ferrara, F., Njai, D. M., and Gaburro, D. Exocrine pancreatic function in premature and full term neonates. Pediatr. Res., 6: 880 (1972).

31. Requests for reprints should be addressed to: Emanuel Lebenthal, Division of Gastroenterology and Nutrition, Children's Hospital of Buffalo, 219 Bryant Street, Buffalo, New York 14222.

32. This research was supported in part by NIH grant $\not 12586$ and NSF grant \#PCM-8021817.

33. Received for publication February 9, 1982.

34. Accepted for publication May 17, 1982.

35. This work appeared previously in abstract form: Pediatr. Res., 16: I65 (1982)

Copyright $(C) 1983$ International Pediatric Research Foundation, Inc. $0031-3998 / 83 / 1701-0015 \$ 02.00 / 0$ 